\title{
Financial Sustainability of Waste Management Service : A Case Study of Pokhara Sub-Municipal Corporation Keshar J. Baral
}

\section{Abstract}

Using the data set provided in the Cost Recovery System of the Waste Management System of Pokhara Sub-municipal Corporation (PSMC), the financial sustainability of the proposed waste management has been examined in this article. Financial sustainability indicators-operating cost ratio and cash operating ratioshow that the proposed system is financially sustainable provided that PSMC imposes the tourist fee and uses the revenue raised from the tourist fee to run the sanitary landfill site, build up the necessary institutional arrangement and capability required to run the designed system and recover the operation cost from the users.

\section{Background}

His Majesty's Government/Nepal and Asian Development Bank (ADB) signed a Loan Agreement for Second Tourism Infrastructure Development Project (STIDP) on August 27, 1996. The basic objective of STIDP was to address the environmental and infrastructure deficiencies that constrained tourism in Nepal. This project had four components-Pokhara Environmental Improvements, Ecotourism Development, Domestic Airport Upgrading, and Implementation Assistance and Institutional Strengthening. Pokhara Environmental Improvements Project (PEIP) had six subcomponents-i. Public Environment Education, ii. Sanitation Facility Improvements, iii. Septage Management, iv. Solid Waste Management, v. Road Improvements and vi. Drainage Improvements. Its twin strategic objectives were to improve the environment of Pokhara and protect the scenic and aesthetic value of Phewa lake (ICT and SAIC 1995, 1: III-1). Proper waste management service plays a key role in keeping the urban environment healthy. Therefore, project had emphasized the proper waste management service. PEIP launched the sanitation improvements loan program, public environment education, and constructed septage treatment plant and landfill site to manage the waste properly and improve the urban environment. It had designed and proposed the total waste management service system for Pokhara Sub-municipal Corporation (PSMC). In this article, attempt has been made to look into the financial sustainability of this system. 


\section{Methodology}

Sources and Nature of Data : The study has used the secondary data and information. Main source of the required data and information is the cost recovery report prepared by the then financial advisor to PEIP. Basically, data on the operation cost-measured in both cash and non-cash expenses-of the proposed waste were cxtrent for financing the operation cost were $\mathrm{cxtracted}$ from this report. Supporting data and other qualitative information between HMG/Nepal and $\mathrm{ADB}$, between HMG/Nepal and PSMC, loan agreement capital invested in bual and and project report. In addition, data on the loan waste management was colleted frastructure required to operate the proposed waste management was collected from PEIP office. The data on the loan capital invested in building the required infrastructure and equipment and vehicles were cross checked by consulting the then project-in-charge, PEIP.

Measurement of Sustainability: For the purpose of the analysis, sustainability has been defined as the capacity to meet the operation cost of the proposed waste management service of PSMC. In addition, the capacity of PSMC to meet the operation cost depends largely on its revenue generating power. It can meet the revenue from general purpose taxes, and use it up for operation of proposed waste management service system and an from specific sources. Thus in totality and isolation principle for covenant, PSMC have to follow the principle of full cost recovery principle (MOTCA 1996, 5/7). In such a case, analysis has been done in isolation. The finanopriate. Therefore, analysis of sustainability indicators: $i$. cash operon. The financial sustainability has been measured by two financial sustainability is ratio, and ii. operating ratio. In the former case, latter case, it is measured by reved by revenue to cash operation cost ratio and in cash-ratio. Thus, these two revenue to total operation cost-both cash and noncash-ratio. Thus, these two indicators are given by:

$\mathrm{Y}=\mathrm{R} / \mathrm{CO}$

Where,

Yc=cash operating ratio

$\mathrm{R}=\mathrm{revenue}$ raised for the operation of proposed waste management service system

$\mathrm{CO}=$ cash operation cost of proposed waste management service system

$\mathrm{Y}=\mathrm{R} / \mathrm{TO}$

Where,

$\mathrm{TO}=$ total operation cost of proposed waste management service system, and
$\mathrm{Y}=$ operating ratio, and

$\mathrm{R}$ denote the same as in model (1)

3. Operation Cost of Proposed Waste Management Service System

The proposed waste management service system has three

Financial Sustainability.., : K.J. Baral components- 1 , solid waste management 2 , septage management and 3 . sanitary landfill site. Further, solid waste management service has four sub-components: $\mathrm{i}$. street/public place cleaning, ii. door to door service, iii. container service and iv. pick-up service. Altogether 85 employees of different levels, and different types of equipment and vehicles-handcart, tricycle, mini-garbage compactor, mini-dumper placer, skip/container, tipper, bull dozer, shovel loader, suction tanker, jetting vehicle - will be required to operate the system. If the system were to operate in the fiscal year 2003/04, around Rs. 33 million operation costs would have been incurred. Of this, around Rs. $13(39 \%)$ million would have been required to run the landfill site constructed at Bachebuduwa, Rs. $17(52 \%)$ million for solid waste management service, and Rs. $3(9 \%)$ million for septage management service. Of the total operation cost of the system, around $52 \%$ is solid waste management service cost. Out of the operation cost of solid waste management service system, street cleaning service would have to cost Rs. 7 million, door-to-door service Rs, 6 million, container service Rs. 3 million and pick up service Rs. 2 million. However, due to the delay in the procurement of required equipment and vehicles, municipality has yet to run the landfill site. It has already acquired some of the required equipment and vehicles, and waiting for others. Municipality will have to bear more than this cost in the years to come if it runs the system as it is. The operation cost will increase year by year due to the increase in the municipal waste and inflation.

In addition to the operation cost stated in foregoing paragraph, municipality has to serve its debt capital also. It has already committed Rs. 160 million loan capital. Of this, Rs. 46 million is not directly related to the proposed system. Thus. the total loan capital directly related to the waste management service system comes around Rs. 114 million. According to the sub-loan agreement between $\mathrm{HMG} / \mathrm{Nepal}$ and PSMC signed on August 27, 1996, PSMC has to serve the loan with $8 \%$ annual interest on outstanding loan on half yearly installment basis for 18 years (HMG/ Nepal and PSMC 1996, 2). ${ }^{1}$ Thus, it will have to incur around Rs. 9 million financing costs in the early years and, later on, it will decrease gradually.

\section{Financing the Operation Cost}

As stated earlier, PSMC would have to incur around Rs. 33 million to run the proposed waste management service system in the fiscal year 2003/04. In principle, PSMC should fully recover the costs of septage and solid waste management services provided in its jurisdiction (Kingdom of Nepal and Asian Development Bank 1996. 35 ). For this, PSMC has already developed a cost recovery scheme. According to this scheme, PSMC will have to finance the operation costs by the revenue raised from these sources-waste management service charges, tax on recyclable waste, and tourist fee. Different types of waste management service charges-solid waste collection and disposal charge, septage collection and disposal service charge, septage disposal charge, private container service charge, solid waste disposal

1. PSM has to repay the due installment on 15 January and 15 July in ench year to HMGNepat. 
charge, construction material disposal service charge, sanitation service charge-are proposed in the scheme (Baral 2001, 7-28),

As discussed in the foregoing paragraph, the proposed waste management service system will provide door to door service; pick up service, container service, and street/public place cleaning service under solid waste management service. The cost recovery scheme has assumed that PSMC will fully recover the operation cost of solid waste management service from its customers. Hence, it will provide the service on cost recovery principle. It has proposed the different types of service charges for different types of direct waste management services-door to door service and private pick up service. In addition to the charges for direct services, it has proposed the annual sanitation fee for households and business entities not receiving the direct waste management service. The logic behind this is that they receive the benefit indirectly from keeping the urban environment clean and healthy. The 5th municipal council meeting held on August 11,2000 had approved the tariff on all these waste management services. However, PSMC has yet to implement it. For the time bcing, it is providing a kind of door to door waste collection service on free of cost. However, it has to implement the scheme immediately after the operation of the landfill site.

As stated earlier, the landfill site operation cost is around $39 \%$ of the total operation cost. In absolute term, the annual landfill site operation cost will be at least Rs. 12 million. PSMC will have to incur around Rs. 12 million operation cost annually. This component of the operation cost is the most unmanageable. The scheme has proposed two sources-tourist fee and tax on the export of recyclable/reusable wastefor financing the landfill site operation cost. After discussing the concept paper on tourist fee prepared by the then PEIP consultant intensively with local representatives of political parties, business communities, and concerned authorities, tourist fee was proposed. Municipul council has already approved the tourist fee in policy. The cost recovery scheme has proposed that $25 \%$ of the revenue raised from tourist fee should be used to meet the landfill site operation cost and the rest to maintain and repair the existing infrastructure, and develop the new one. It has proposed to meet almost all landfill site operation cost from tourist fee. PSMC will finance only $10 \%$ of landfill sitc opcration cost from the revenue raised from the tax on the export of recyclable/reusable waste. Thus, PSMC will finance the operation cost of proposed waste management service system from the revenue raised mainly from the beneficiaries-direct and indirect, and from the waste related local tax.

\section{Analysis of Financial Sustainability}

PSMC, financially, will not be able to sustain the proposed waste management service with the crstwhile financial condition and institutional arrangement. In the fiscal year 2002/03, total revenue raised from its own sources was around Rs. 68 million. Of this, around Rs. 40 million was the local development fee-transitional replacement of octopi. The dominancy of a single source in revenue raised from owns source shows the fragile financial condition. Nepal has already been a full fledged member of World Trade Organization (WTO). She will be bound to abolish the local development fee in a few years of the entry into WTO as set in the protocol signed by her. Thus, the lifting of the turnpike of local development fee will engulf not only PSMC but also other municipalities into the financial crisis. Therefore, municipalities should develop their own reliable source of revenue as an alternate to the local development fee. Property related taxes might take the place of present local development fee. However, the erstwhile financial system of almost municipalities indicates that the revenue raised from property related taxes is not taking place of local development fee in near future. In the case of PSMC, it has established the primary ground for property related taxes but has to do a lot to mobilize the local resources through them. Therefore, it also will not be able to do away the severe resource crunch after abolition of local development fee.

For PSMC, it is not possible to run the proposed waste management system and render any urban services on free of cost. Therefore, it will be bound to follow the give and take principle. This will be the only way out to provide the basic urban services. Nevertheless, it will not be able to provide the minimum urban services to the urban populace on the abolition of local development fee. It has already adopted the give and take principle but has yet to implement it. As stated earlier, it will have to recover fully the operation cost of solid waste management service and septage management service from users to make it sustainable. However, the major problem for municipality is how to recover these costs from users. The problem is not on the part of the users but on the part of municipality. At the time of designing the cost recovery scheme, intensive consultation program with the user groups like Tole Sudhar Samittec was launched. During the consultation, it was found that almost all households were ready to pay the reasonable waste management services charge. But the only condition of the users was the regularity of the service. Almost all Samittees raised a doubt whether municipality could run the service regularly. After approval of municipal council on proposed scheme, opinion survey on proposed service charges was carried out. This survey also concluded that users are ready to pay proposed service charges (Karki, 2001).

As stated in methodology, financial sustainability largely depends on the capacity of municipality to meet the operation cost of the proposed system. Capacity of municipality to meet the operation cost can be analyzed in two perspectives- in totality and in isolation. Financial analysis in totality becomes meaningful only when there is possibility of meeting the operation cost of particular service from the revenue raised from sources other than the specific service. Analysis of present financial condition of PSMC shows that there is no possibility to meet the operation cost of proposed waste management system from general taxes on one hand and on other, PSMC is bound to recover its operation cost from users. So, here, the capacity of meeting the operation cost has been analyzed in isolation.

For the purpose of the analysis of financial sustainability of the proposed waste management service system in isolation, data on operation cost and revenue of the proposed system have been extracted from the cost recovery scheme. Revenue has been analyzed on thesc four scenarios: 
First Scenario (SI)

In this scenario, revenue was estimated on the following assumptions:

- Every household will clean the septic tank in every six years.

- PSMC will impose the tourist fee and $25 \%$ of the revenue raised from it will be used to meet the operation cost of solid waste management service system. Second Scenario (S2)

In this scenario, revenue was estimated on the following assumptions:

- Every household will clean the septic tank in every twelve years.

- PSMC will impose the tourist fee and $25 \%$ of the revenue raised from it will be used to meet the operation cost of solid waste management service system. Third Scenario (S3)

In this scenario, revenue was estimated on the following assumptions:

- Every household will clean the septic tank in every twelve years.

- PSMC will not impose the tourist fee.

Fourth Scenario (S4)

In this scenario, revenue was estimated on the following assumptions:

- Every household will clean the septic tank in every six years.

- PSMC will not impose the tourist fee.

As stated in methodology, sustainability has been measured in term of estimated revenue to operation cost ratio and revenue to cash operation cost ratio. In cash operation cost measurement, non-cash operation cost especially depreciation cost is excluded and this will show whether the proposed system will generate enough revenue to meet its cash operation cost. The worked out ratios for 13 years to come under four scenarios are given in Appendix 1 .

In reality, realization of these two assumptions-imposition of tourist fee and cleaning the septic tank in every six years-is seemed in very distance. Since, the septic tanks in most of the houses and business enterprises are not sealed. Geologically, such septic tanks will not be required to clean up in 5 years. PSMC should have to enforce its Sanitation By-laws strictly ${ }^{2}$ to make valid the second assumption. But it does not seem easy due to the lack of political commitment and unnecessary political interfere. Although municipal council has already approved the policy on tourist fee, it is very difficulty to implement it. Municipality, HMG/ Nepal, and business community may be at loggerheads due to the proposed tourist fee if municipality fails to implement its scheme properly. Operating ratios in first and second scenarios during the projected period 'fiscal year 2003/04 through 2015/ 016) are greater than one. These ratios show that PSMC will be able to meet the operation cost of the proposed system and have surplus funds to serve its debt capital. But these ratios in third and fourth scenarios are either less than one or slightly greater than one. Thus, these ratios indicate that proposed system is not financially sustainable without charging the tourist fee.

The second ratio-cash operating ratio, measures whether the proposed system

2. PSMC \& Saniration By-laws has a provisixan thet every trousebold and busp

Conk will generate cash enough to meet the cash expenses. As stated earlier this measure includes only the cash expenses and excludes non-cash expenses like depreciation and amortization. The projected cash operating ratios indicate that proposed scheme of revenue is enough to meet the cash operation expenses in all scenarios. The projected ratios in first and second scenarios indicate that there will be cash surplus to meet the debt obligation also but in third and fourth scenarios, these are slightly higher than one. These indicate that there will not be enough cash surplus to meet the debt obligation and be no possibility to recover the investment. Due to this, municipality will have to search for donors for future capital investment and repay the loan from the revenue raised from sources other than the waste management service charges. This is the reason why PSMC will be bound to impose the tourist fee as proposed in the scheme and use $25 \%$ of revenue raised from it to run the sanitary landfill site.

\section{Question of Sustainability}

Again and again, the local people of the landfill site had raised the question on the smooth operation of proposed landfill site and opposed the landfill site vehemently during its construction phase. The local people and urban populace raised the question on the institutional capability of PSMC and intention of the local politicians in the implementation of the proposed system. At present, it does not have institutional capability to run the proposed system on one hand and on the other, local politicians can distort the system on their own vested individual and political interest. This is the prime reason why urban populace does suspect about the smooth operation and sustainability of the system. The next reason of suspicion on the sustainability of the proposed system is the present municipal organization culture.

Readiness to pay the service charge is not enough for sustainability of the proposed waste management system. It is prerequisite for providing the service but not for sustainability. In order to make the users to pay the levied service charges, first of all, they should be satisfied with the provided services. PSMC has to set up the required institutional arrangement to provide the service and collect the due charges regularly on one hand and on the other, it should have strong commitment for corruption free and efficient administration with efficient and well motivated work force. But still there is a question marks on the efficiency of municipality in providing users the proposed service and collect the service charges. In spite of the potential financial sustainability, proposed system may not be sustainable due to the inefficient municipal service and political logrolling.

\section{Remedial Measures}

The following remedial measures are forwarded to make the proposed system sustainable:

7.1. The earlier analysis shows that proposed system will not be financially sustainable without the imposition of tourist fee and levying any service charges. Municipality itself can not run all types of basic urban services. It should initiate the private sector to run some of the components of the system and run the program to make the people aware about the waste management. The way out of making the system 
sustainable is either to reduce the operation cost or to generate the enough revenue to meet the operation cost. Privatization of the service and reduction in the waste generation are the best ways of cutting down the operation cost of the proposed system.

7.2. The then financial advisor to the project had advised PSMC to privatize the collection of reusable/recyclable waste through franchise agreement. The proper management of the collection of recyclable/reusable waste reduces the operation cost of the system and helps to increase the revenue raised from the export of reusable waste and royalty of waste. It reduces the operation cost of the proposed system by reducing the landfill site waste. At present around $66 \%$ waste is reusable/recyclable. Proper management of collection of reusable/recyclable waste means reduction in landfill waste up to $66 \%$ of waste in volume (Gunung 2004,48). Reduction in the landfill waste implies the decrease in the waste collection, transportation and landfill operation costs, and increase in the life span of the landfill site. The study carried out recently shows that PSMC can save minimum $17 \%$ and maximum $66 \%$ of its waste management cost (Gurung 2004, 86). In addition, proper management of collection of reusable/recyclable waste helps to generate the regular income of city dwellers and keep their environment neat and clean. This may motivate them to pay the waste management service charge regularly. ${ }^{3}$

73. The waste can be reduced by launching awareness campaign especially about the separation of waste into organic and inorganic, and separation of waste into reusable/ recyclable and landfill site waste; the importance; and use of waste. Basically, waste generators should conceive waste as resource not as liability. So, municipality should launch the massive awareness campaign about the waste management continually.

7.4. Municipality can reduce the operation cost of proposed waste management system by privatizing its certain components. Street/public place cleaning and door to door service are the appropriate components for private sector. The estimated operation cost of these two components is around $39 \%$ of the total cost. Municipality can bring down the operation cost of the proposed system by contracting out these components to the private company on cost plus specified percent term. It is obvious that private party carries out any activities for profit motive. Municipality should permit the private party to mark its service up to a reasonable profit margin, sell them to customers, and recover the cost from the customers in term of monthly service charge. The experience of private companies providing the waste collection service in Biratnagar and Kathmandu municipalities shows that the disintegration of street cleaning and door to door waste collection service is not effective in the collection of service charges. So, in order to motivate the private sector to render waste management service on give and take principle, both street cleaning component and door to door component should be contracted out to the same private party.

7.5. Finally, operation cost can be reduced by setting up the composting plant based on the indigenous technology. Composting site is the main problem for composting the organic waste. So, it should be constructed at adjoining area of

\footnotetext{
3 The then finuncial advisor had prepared and submitted the Marayement Plan for the Operation of Franchise Agreement for the Collection, Purchase, and Sale of Reusable/Recyclable Muricipal Waste to PSMC in July 2002 . PSMC has already signed the franchise agreement with a privatc company but it has yet to come in its fall operation.
}

landfill site. The sole responsibility to run the composting site should be given to the private party, if possible, to the municipal employees. Doing so, municipality can cut the operation cost down in two ways-increasing the life span of landfill site and recovering certain percent of one way transportation cost of waste. ${ }^{4}$ The same vehicle may be used to transport the manure from the site to the farm. Municipality may charge the freight for transporting the manure from the site to the farm and recover certain percent of transportation cost of waste.

\section{Concluding Remarks}

In conclusion, successful implementation of the proposed waste management service system for PSMC is the challenging job but essential to meet its financial obligation and discharge the duties as a local government. Failure to implement the proposed system successfully implies not only the ineffective use of loan capital but also the mistrust of the donors for future development programs due to the default in the payment of due installment of loan. Failure to implement the proposed system affects the tourism adversely through the degradation of urban environment. So business community also should co-operate PSMC for its successful implementation. PSMC should first set up the required institutional arrangement and then implement the system gradually to keep the healthy urban environment and promote the tourism in Pokhara, win the trust of the donors, and discharge the responsibilities to the urban populace as a local government.

Appendix 1

Operating Ratios of Proposed Waste Management System

\begin{tabular}{|c|c|c|c|c|c|c|c|c|}
\hline \multirow{2}{*}{ Year } & \multicolumn{4}{|c|}{ Operating Ratio } & \multicolumn{4}{c|}{ Cash Operating Ratio } \\
\cline { 2 - 9 } & $\mathbf{S}_{1}$ & $\mathbf{S}_{2}$ & $\mathbf{S}_{3}$ & $\mathbf{S}_{4}$ & $\mathbf{S}_{1}$ & $\mathbf{S}_{2}$ & $\mathbf{S}_{3}$ & $\mathbf{S}_{4}$ \\
\hline 2004 & 1.30 & 1.26 & 0.88 & 0.92 & 1.70 & 1.64 & 1.14 & 1.20 \\
\hline 2005 & 1.22 & 1.18 & 0.84 & 0.88 & 1.54 & 1.49 & 1.06 & 1.11 \\
\hline 2006 & 1.36 & 1.23 & 0.90 & 0.94 & 1.70 & 1.54 & 1.12 & 1.17 \\
\hline 2007 & 1.39 & 1.29 & 0.92 & 1.00 & 1.70 & 1.58 & 1.13 & 1.23 \\
\hline 2008 & 1.34 & 1.25 & 0.91 & 0.99 & 1.60 & 1.49 & 1.09 & 1.18 \\
\hline 2009 & 1.31 & 1.23 & 0.92 & 1.00 & 1.55 & 1.45 & 1.08 & 1.18 \\
\hline 2010 & 1.34 & 1.26 & 0.96 & 1.04 & 1.58 & 1.48 & 1.13 & 1.22 \\
\hline 2011 & 1.34 & 1.26 & 0.98 & 1.06 & 1.55 & 1.46 & 1.13 & 1.22 \\
\hline 2012 & 1.39 & 1.27 & 0.98 & 1.10 & 1.64 & 1.50 & 1.15 & 1.29 \\
\hline 2013 & 1.41 & 1.29 & 1.01 & 1.13 & 1.64 & 1.51 & 1.18 & 1.32 \\
\hline 2014 & 1.34 & 1.23 & 0.98 & 1.09 & 1.54 & 1.41 & 1.13 & 1.26 \\
\hline 2015 & 1.44 & 1.32 & 1.08 & 1.20 & 1.64 & 1.51 & 1.23 & 1.37 \\
\hline 2016 & 1.39 & 1.27 & 1.04 & 1.16 & 1.58 & 1.44 & 1.18 & 1.31 \\
\hline
\end{tabular}

Source : Calculation is based on data given in Cost Recovery Scheme of Septage and Solid Waste Management System, 2007. Appendix 2.1 and 2.2

4 The then firancial advisor had advised PSMC to construct the composting site adjoining to the landfill site and contract out the site to the private company. 
References

Baral, Keshar J. 2001. Cost Recovery Scheme of Septage and Solid Waste Management System. Final report. Pokhara : PEIP.

Gurung, Sushma. 2004. The Financial Implication of the Proper Management of Recyclable/Reusable Wastes : A Case Study of Pokhara Sub-municipal Corporation. Master diss., T.U.

HMG/Nepal and PSMC. 1996. Subsidiary Loan Agreement between HMG/Nepal and Pokhara Sub-Metropolis. Kathmandu.

Intercontinental Consultants and Technocrats Pvt. Ltd (ICT) and Science Application International Corporation (SAIC). 1995, Second Tourism Infrastructure Development Project: TA 2140 NEP. Vol. 1. A project report (Final), Asian Development Bank.

Karki, Shambhu. 2001. Opinion Survey on the Proposed Waste Management Service Charges in Pokhara Sub-Municipal Corporation. Master diss,, T.U.

Kingdom of Nepal and Asian Development Bank. 1996. Loan Agreement (Second Tourism Infrastructure Development Project) between Kingdom of Nepal and Asian Development Bank. Manila.

Ministry of Tourism and Civil Aviation (MOTCA). 1996. Second Tourism Infrastructure Development Project: Project Administration Memorandum. Manila: Asian Development Bank.

$* * *$

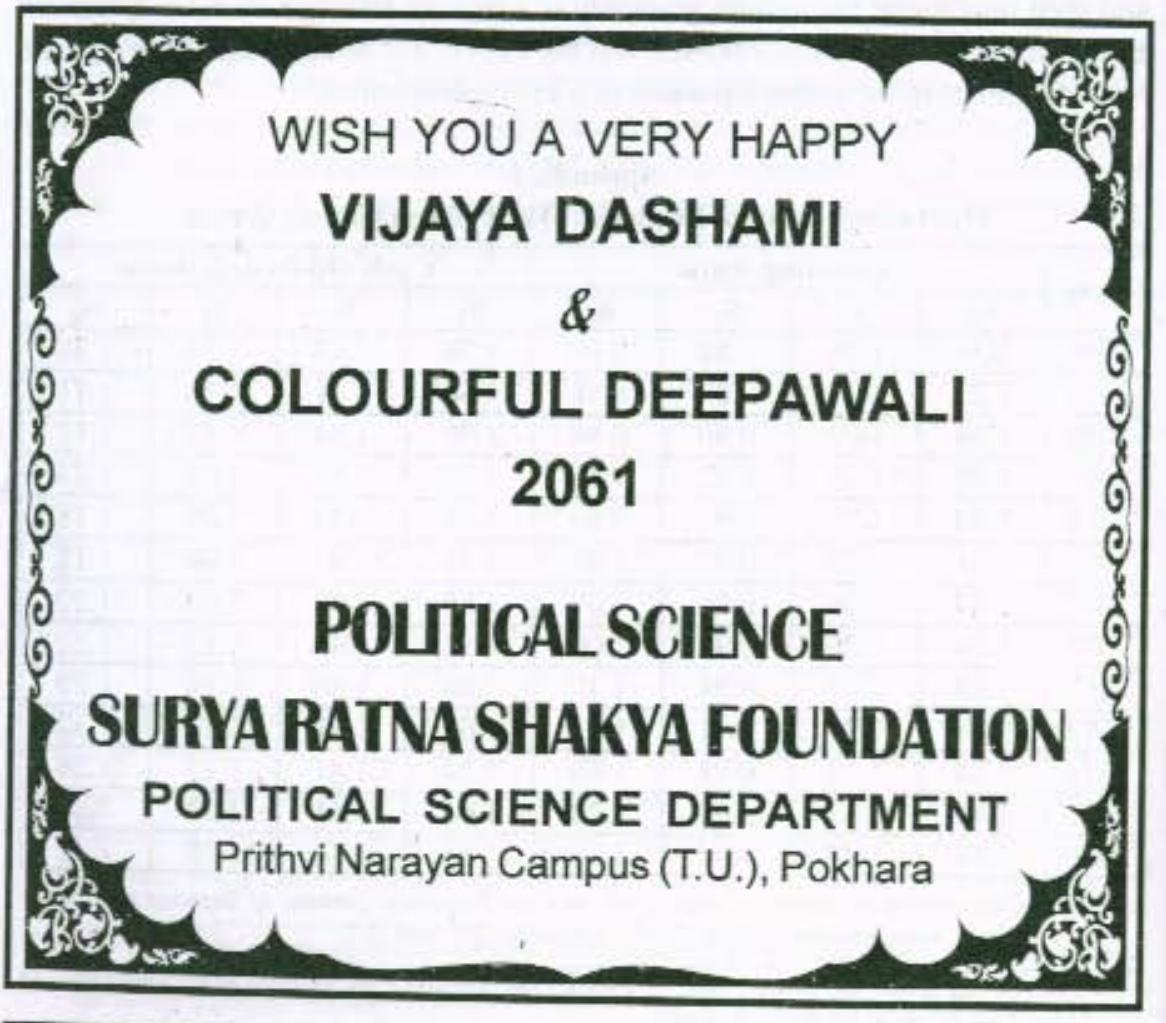

Financial Sustainability... : K.J. Baral 